\title{
モクズガニEriocheir japonica (de Haan) の繁殖生態（総説） Reproductive Ecology of the Japanese Mitten Crab Eriocheir japonica (de Haan): a Review.
}

\author{
小林 哲* \\ 京都大学農学研究科底用生物科学専攻海洋生物機能学分野。 $\overline{7}$ 606-8502 京都市左京区北白川追分町 \\ Satoshi KOBAYASHI* \\ Division of Marine Biological Function, Department of Applied Biology, Faculty of Agriculture, Kyoto University, \\ Kitashirakawa Oiwake-cho, Sakyo-ku, Kyoto 606-8502, Japan.
}

\begin{abstract}
Reproductive ecology of the Japanese mitten crab Eriocheir japonica (de Haan) is reviewed mainly based on information collected over the last ten years. This crab is a catadromous species which grows to maturity in freshwater and reproduces in brackish waters and the sea. Adult crabs migrate downstream from fully freshwater areas to marine tidal areas for the purpose of copulation, oviposition, and hatching of eggs. Megalopa larvae settle and metamorphose to the crab stage in upper brackish areas after planktonic zoea larva stage in the sea. Juvenile crabs migrate upstream to freshwater and disperse widely along the river. Larger crabs are distributed in the upper reaches. In both sexes, in the upstream direction the population density tends to decrease, and size at maturity tends to be larger, and the sex ratio becomes female-biased. Details of the process and timetable of maturation (puberty moult and gonad maturation), downstream migration, mating behaviour, oviposition and hatching, the planktonic life of the zoea larvae, and the settlement of the megalopa larvae are noted and their ecological significance is discussed. Ovarian maturation occurs after the puberty moult (terminal moult), taking approximately 4 months. Adult crabs in a hard-shell condition migrate downstream to the tidal area and participate in reproduction, but females migrate downstream even if they have not completed maturation. There are two groups of females that differ in the timing of reproduction. The early-maturing group, which is small in number, develops ovaries in September or October and oviposits in October. In the late-maturing group, which is larger in number, the puberty moult occurs in August, maturation is generally complete by December, and oviposition occurs after December. Mating is initiated without any precopulatory behaviour. Females do not use a sex pheromone to attract mates and males approach without determining the receptivity of the females. Females can copulate only after their ovaries have matured, and they lay eggs within a day after copulation. However, females are not necessarily in a receptive condition in the tidal area, and approaching males are often rejected by females with not fully matured ovaries. The duration of copulation is from 13 to 43 minutes and is negatively correlated with water temperature. Postcopulatory guarding by males continues for several hours, and females may be released by males when oviposition occurs. Females often reject guarding by small males. Females oviposit and hatch eggs up to a maximum of three times. The number of eggs tends to decrease in later clutches. Most crabs seem to die after reproduction without further moulting. Size at maturity varies from approximately $35 \mathrm{~mm}$ to $75 \mathrm{~mm}$ in carapace width, but each crab can participate in reproduction only in one season and cannot thereafter grow larger. Thus, there is a wide variation of reproductive success in E. japonica. In the females, fecundity is higher in larger crabs. As for the males, larger ones with larger chelipeds can most effectively guard females after copulation. The duration of embryonic development varies from 2 weeks to 3 months, and that of the planktonic life of zoea larvae in the sea is estimated to vary with water temperature. Settlement of megalopa larvae in the upper tidal reaches occurs from 2 weeks to 4 months after hatching, depending on the river, and it takes place mainly in mid-autumn (October) and early summer (May to June). The young crabs that metamorphose in autumn and winter neither migrate nor grow during the winter. Upstream migration of the autumn settlers and the summer settlers to freshwater occurs from March to June and from July to August, respectively. This mode of settlement with two peaks reflects the temporal pattern of reproduction. Autumn
\end{abstract}

Received 30 Mar 1999 Accepted 22 Jun 1999

*: Corresponding address: 
settlers are derived from the eggs produced by the early-maturing females, and summer settlers from the latematuring ones. The reproductive strategy of this crab is of the type characterized by the production of a large number of small eggs and the dispersion of planktonic larvae at sea area in order to colonize new areas. This reproductive strategy may help the crabs to maintain a wide distributional range and make it possible for them to avoid local extinction regardless of high fishing pressure. Gene diversity analysis has also indicated that genetic differentiation of local populations is small. Recent maintenance and restocking efforts of crab populations by fishermen, e.g., through fishery regulation, seed production, and release of crabs, are also discussed. Finally, topics concerning the congeneric catadromous species $E$. sinensis $\mathbf{H}$. Milne-Edwards are considered in comparison with the situation of $E$. japonica. The former species is a native of China, but it has become dispersed into Europe and North America in the 20th century and threatens the native community in these new habitats. The invasion potential of this crab may be enhanced by its reproductive strategy, which utilizes the dispersion of planktonic larvae to colonize new areas.

Key Words: Eriocheir japonica (de Haan), life history, catadromous migration, maturation size gradient, reproductive strategy.

\section{はじめに}

モクズガニEriocheir japonica（de Haan）はロシアの沿海 州, サハリン, 朝鮮半島東岸部, 北海道から琉球列島, 小 笠原諸島までを含むほほ日本の全域，台湾に分布するイワ ガニ科のカニである (酒井 1976). 本種は河川の淡水域上 流部から汽水域，沿岸海域にかけて広く分布する大型底生 動物として水生生物群集の中で重要な位置を占めており, また淡水域と海水域を行き来する数少ない通し回遊性の力 ことしても知られている. 一方, 内水面漁業における重要 な漁獲対象種として日本各地の河川でカ二かご，うけなど により捕獲されているが，近年乱獲の影響が心配されてお り，各地の漁協が漁獲制限を設けるとともに種苗生産や稚 ガニの放流を行っている．また堰やダムの建設など河川工 事によって回遊と分布に影響を受ける種として注目されて おり，河川生態系を管理する上でその移動経路を確保する ため魚道に対して何らかの方策を講じることが望まれてい る（野中 1994; Kobayashi 1998; 小林 1999)。このように特 異な生態を持ち, 重要な漁獲対象種であるにも関わらず, 10 年ほど前まではこのカニに関する情報はそしく，沿岸海 域に生息する他の底棲動物や，河川に生息する魚類や水生 昆虫などと比べて生態に謎の部分が多く, 詳しい調査が望 まれていた，その生態について総合的に理解することは， 通し回遊種の生態学的情報を得るという点だけではなく， 河川・沿岸海域の生物群集の保全の面からも，また重要な 漁業资源を保護する上からも重要であろう。筆者は，これ まで様々な観点から本種の回遊と繁殖様式を明らかにして きた（たとえば小林・松浦 1991; Kobayashi \& Matsuura 1994a, 1995a, b, c, d, 1997; Kobayashi 1998)。また, 総説と して一般的な生態を小林・松浦（1995）で紹介し，回遊と 環境との関係を小林（1999）でまとめてきた．本総説では， 保護事業や増殖事業にも役立てられるよう，モクズガニの 繁殖に関する情報をまとめ，それをもとにモクズガニのお かれている現状について考察を加える.

\section{1. 繁殖生態}

\section{1. 通し回遊のプロセス}

回遊とは, 生涯の一時期に一定方向の移動を行い，のち に戻ってくる習性である. 規模の大小はあるものの多くの 水生生物で繁殖場所と生育場所間の移動が知られるが, 中 でも通し回遊は塩分濃度差の大きい淡水域と海水域の間を めぐる回遊で, 移動能力の発達した魚類では詳しく調べら れている (Myers 1949; McDowall 1992; 塚本 1994). 通し回 遊は大きく 4 タイプに分けられる。（1）遡河回遊は，淡水 域で産卵が行われ，睬化した幼体がしばらくしてから海域 へ降り，海域で成長したのち成熟個体が川を遡る（サケ・ マス類など)。（2）降河回遊は，成熟個体が川を降り海域 で繁殖し、海域で生まれた幼体が川を遡って淡水域に達し 成長する (ウナギやヤマノカミなど), 両側回遊は, 成長 の場と繁殖の場が同じ塩分濃度であり, 成長の一時期だけ 塩分濃度の異なる水域へ移動するものである。これには起 源の異なる 2 通りがあり，（3）淡水性両側回遊は, 淡水域 で成長し繁殖するものの躬化後しばらくして幼体が海域へ 移動し，しばらく海域で過ごしたあと淡水域へ戻って成長 を続け（アユやヨシノボリなど），(4）海水性両側回遊は 海域で成長・繁殖する種が生活史の一時期に淡水域へ進入 して過ごす（ボラやスズキなど）。なお，遡河回遊魚や淡 水性両側回遊魚の中には, サクラマスでのヤマメや, サッ キマスでのアマゴのように, 生涯焱水域内で過ごす陸封化 集団が見られることがある.

モクズガニの生活史を Fig. 1 に示した。.モクズガ二は慗 殖のため成体が川を降り，塩分濃度のある程度高い河川感 潮域の下流部から海域に達し，そこで繁殖を行う。繁殖は 河口域から海域で行われる（Kobayashi \& Matsuura 1995b, c).一方艀化したゾエア幼生は，プランクトンとして海域 に分散すると考えられる.ゾエア幼生は 5 回の脱皮を経て 遊泳能力の発達したメガロパ幼生に変態し（森田 1974a）, 幼生は河口域を遡り感潮域上限部に着底し底生生活に移 


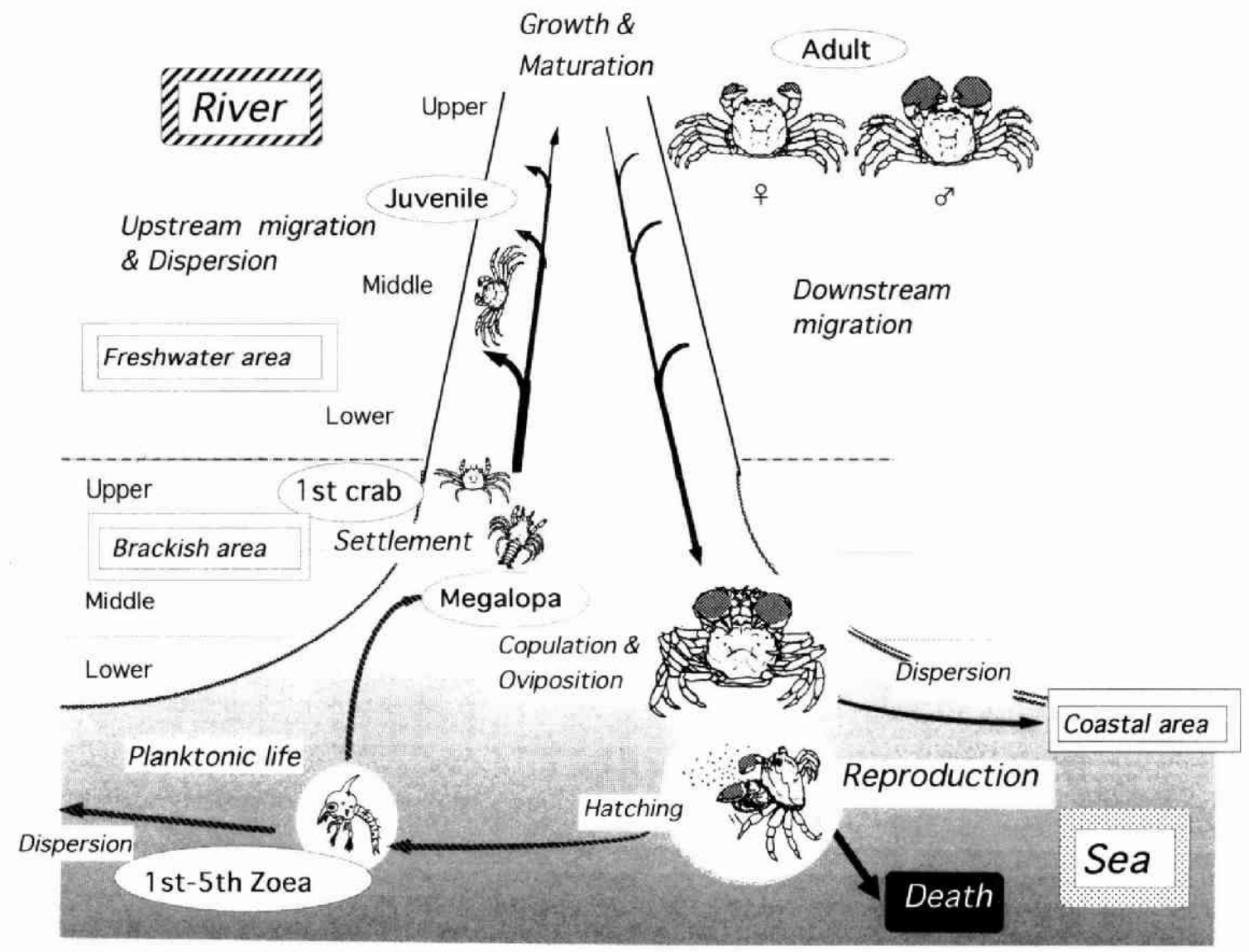

Fig. 1. Schematic diagram of the life history and migration pattern of Eriocheir japonica.

る。やがて稚ガニに変態してしばらく感潮域に留まったあ と, 河川の上流域へ向けて遡上を開始し, 淡水域へ達した あとも成長を続けながら遡上・分散する (Kobayashi 1998). したがってこのカ二は降河回遊型である．河川に生息する エビ類（ヌマエビやテナガエビ類）の多くが淡水性两側回 遊型である（諸喜田 1979）のに比べると，モクズガニは淡 水域では交尾・産卵在行わず (小林・松浦 1991), 幼生も 塩分濃度がある程度なければ生存できず（石田 1976)，海 域には通常成体しか出現しない（Kobayashi \& Matsuura 1995b) など明瞭に異なる.また淡水性エビ類（又マエビ やテナガエヒ類）には両側回遊個体群と陸封化個体群の両 者が認められる種があるが (Mashiko 1990)，モクズガニに は淡水域で生活史を全うする個体群は知られていない。

\section{2. 淡水域における成長と成熟}

本種は河川の淡水域で脱皮成長を繰り返し, やがて繁殖 可能な成体となる. 形態的な性差は 4 龄稚ガ二の段階で腹 肢の本数の違いとして現れている（森田 1974a）。淮では成 長とともに腹節幅の相対的な増大が認められ，特に成体で は抱卵に役立つよう腹節が顕著に発達するため, 未成体と 明瞪に区別できる。そのため未成体が成長時に行う脱皮 (成長脱皮) と末成体から成体になる脱皮（成熟脱皮）と を区別することができる(小林・松浦 1992). 雄について
も同様に成熟脱皮が存在すると推察できるが，外部形態に より成体を未成体と区別できないため, 確認はできない. また雏雄とも成長するにつれて鉗脚が大型化するとともに 鉗脚上軟毛の分布域が拡大寸る傾向があり，特に雄では顕 著である。そのため銝脚の雌雄差は成長とともに㹡大し， 成体では雄は軟毛の密生した大型の鉗脚, 倠は軟毛の薄い 小型の鉗脚在持ち、形態に顕著な性的二形が認められる (Kobayashi \& Matsuura 1993).

河川の淡水域でモクズガニは1年を通じ下流部から上流 部まで店く分布しているが, その密度は全体的に上流入向 かうに徉い減少していると推定され，1かご当たりの平均 漁獲量も最上流部は最下流部の 1/7である (Kobayashi \& Matsuura 1995d)。雌では成体のサイズは甲幅 35 75 mm 程 度て大大き幅がある (小林. 松浦 1992). 成熟脱皮は淡水 域の広い分布域で行われるが, 流程に沿って成熟サイズに 変異性か認められる。すなわち，下流域では小型の未成体 が成熟脱皮を行うため, 小型 (甲幅 $55 \mathrm{~mm}$ 末満) の成体 ばかりが採集される。 それに対し, 上流域では大型化した 未成体が成熟脱皮を行う傾向が認められ, 成体は大型個体 (甲幅 $55 \sim 75 \mathrm{~mm}$ ) ばかりが採集される. 分布域全体では 上流入向かうほと最大未成体サイズと最小成体サイズが大 型化する傾问が認められる(小林 - 松浦 1991; Kobayashi \& Matsuura 1995d). 雄についても同様に, 下流域には小型個 


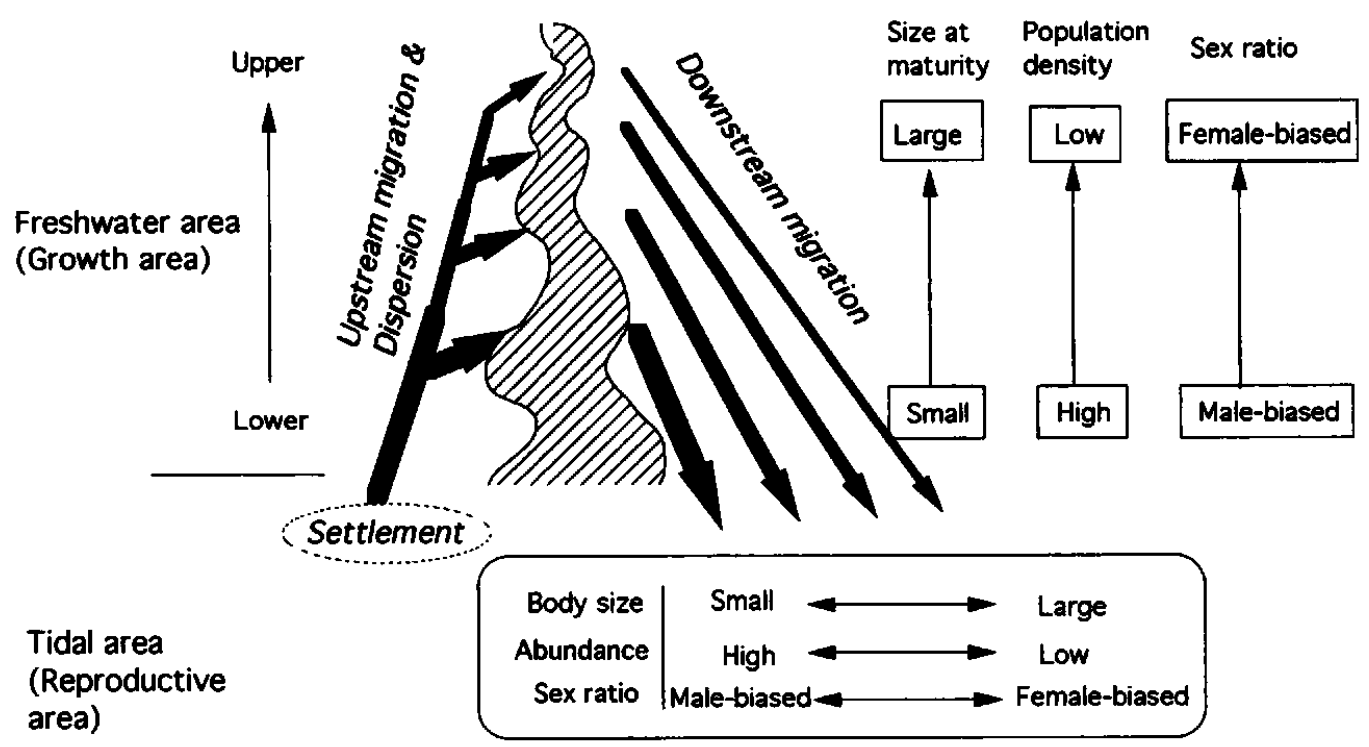

Reproducing group (Adult crabs, total during a season)

Fig. 2. Schematic diagram of the population structure of Eriocheir japonica showing the variation along the river.

体ばかりが分布し，上流域では大型倜体が多数分布してい る.さらに生殖腺（雄の場合精巣と輸精管，副精腺）が顕 著に発達した成体がみられるのも下流域では小型個体（甲 幅 $55 \mathrm{~mm}$ 未満），上流域では大型個体（甲幅 $55 \sim 75 \mathrm{~mm}$ ） に限られ，上流ほど成熟サイズが大型化する傾向がある (Kobayashi \& Matsuura 1995c). 鹿児島県神之川で 1 年間力 二かごにより採集された個体は，雌雄とも最下流域では $90 \%$ 以上が甲幅 $55 \mathrm{~mm}$ 未満であったのに対し, 最上流部 では甲幅 55 75 mm が 60\% 以上を占めていた（Kobayashi \& Matsuura 1995d)。また性比に関しては，上流ほど雌が多 く下流ほど雄が多い傾向が認められ，1 年間にカニかごで 採集された個体は最上流部で雌の比率が $69 \%$ であったのに 対し，最下流部では 43\%であった（Kobayashi \& Matsuura 1995d). 以上のように, 本種は淡水域では流程に沿って連 続した変異性が存在する。

淡水域に分布する成体はやがてすべてが川を降り感潮域 へ達し，繁殖に参加する時に混ざり合う。そのため汽水域 や海域で採集される繁殖参加個体の構成は, 繁殖期全体を 通してみると堆雄とも淡水域の下流域に由来する小型個体 （甲幅 35 55 mm）が多く, 全体の性比は雄に偏るが小型 倜体は雄に, 大型個体は倠に偏る傾向が認められ, 淡水域 での分布様式を反映している (Fig. 2).

このような成熟サイズの変異性を生み出す原因について は，2 通りの説明が可能である．まずそれぞれの個体にお いて成熟サイズが遺伝的に決まっていて，大型成熟個体が 上流まで遡上する傾向が，小型で成熟する個体は下流に留 まる傾向があるというものである，もう一つは本来成熟サ イズは遺伝的に決まっておらず，表現型に可塑性があるた め, 生息環境の影響, たとえば水温, 餌条件, 個体群密度
などにより後天的に決まるというものである．残念ながら， モクズガニでは検証が困難なためいまだ明らかにされては いない(たとえば脱皮成長を行うことにより標識追跡が難 しく, 移動分散が激しく生息域の特徽から再捕効率も悪 い, 高密度飼育下では共食いを行う可能性がある, など). 流程に沿った成熟サイズの連続的変異現象は, 两側回遊 性のカンキョウカジカ Cottus hangiongensis Mori でも確認 されており，河川流程に沿って広く分布域を持つ通し回遊 性種に共通する現象として注目される，カンキョウカジカ では上流ほど成熟年㱓が遅延することで成熟サイズが大型 化することが明らかにされており，またこの变異性は雄で 顕著であり，一夫多妻型の繁殖システムとの関連が推察さ れている，さらに，密度条件の異なる条件下で飼育を行う ことで, 成熟サイズ変異の原因が表現型の可塑性によるも のであり, 成長期の個体群密度という環境の影響を受けて 表れることが明らかにされている (Goto 1993).

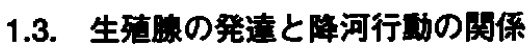

多くの雌は 8 月頃に淡水域で成熟脱皮を行うが, 倠はそ の段階ではまだ卵巣は未熟な段階で，卵黄物質は蓄積して おらず黄白色の細い系状である，その後卵宩の発達が始ま $\eta$, 卵巣内卵は卵径 $100 \mu \mathrm{m}$ 未満加 $300 \mu \mathrm{m}$ 以上へ, 生殖 腺指数（100×卵巣重量／歩脚を除いた䏤体の質重量）で 1.0 末満から 10.0 程度へと顕著な増大が見られる。卵巣の 色も黄白色から橙色を経て赤褐色へと变化する. 卵巣の発 達には少なくとも3 ケ月程度は必要で, 卵巣が成熟するの は 12 月頃になる。一方ごく一部の個体は 8 月の段階で既 に成体として卵巣が発達中であり，9月頃には成熟してい る (早期成熟群)。これらは大型個体に偏る傾向が認めら 
れる (Kobayashi \& Matsuura 1995c).

慗殖に参加するための回遊行動は，モクズガニの場合， 繁殖可能な状態で行われるとは限らない. カ二が川を降る のは成体になってからであるが，卵巣の発達程度との間に 明瞭な関係は認められない. 降河時期は開始も終わりも上 流ほど早く，また一度降河を始めたら途中の淡水域で留ま る傾向は弱く，汽水域へ一気に降る傾向があると思われる (Kobayashi \& Matsuura 1995c)。卵巣の発達は生息場所に関 係なくほほ同時期に行われる．そのため，早い時期に降河 のみられる上流域では, 卵巣の未発達なカ二が降河個体の 多数を占めている．先に述べたように，全体的に河川の上 流域ほど大型個体が分布しており，かつ分布密度が低いた め，上流からの個体が降る繁殖期の始め（9 10月）には, 感潮域に大型個体（多くは甲幅 $55 \mathrm{~mm}$ 以上）が少数分布 しており，卵巣の未熟な個体が多く含まれている，なお， それらの個体の中にはごく一部卵巣が成熟した個体も混 ざっており (早期成熟群)，9月中に繁殖活動を始めてい る。そして降河時期の遅い下流域では，ある程度卵巣の発 達した状態で川を降ることになる．下流域には小型個体が 多数分布しているため，多くの個体が降る 11 月以降には， 感潮域に小型個体を多く含む多数の成体が出現する（小 林.松浦 1991; Kobayashi \& Matsuura 1995b).

成熟した雄では輸精管に精包（精子の詰まった袋）が満 たされている，感潮域ではこのような成熟した雄ばかりが 出現しており，雄はおもに生殖腺の発達した状態で川を降 ると考えられる（Kobayashi \& Matsuura 1995c)。また流域 ごとでは雌雄の降河時期に差は認められず，同時期に降る 傾向が認められる (Kobayashi \& Matsuura 1995c).

\section{4. 配偶行的}

モクズガニの繁殖活動は，河川および海域の感潮域に限 られている，森田（1974b）は河川感潮域での配偶行動の みを確認しているが，筆者は外海に面した海域でもこのカ 二の交尾を確認し，海水飼育下で交尾を盛んに行うのを観 察している (Kobayashi \& Matsuura 1994b). 福岡県津屋崎 海岸でのモクズガ二の繁殖期は，個体群全体では 9 月から 翌年の6月にかけての10ヶ月近くにおよぶ（Kobayashi \& Matsuura 1995b). 交尾もその間観察され，早期成熟群が 9 月から 12 月にかけて，他の多くの個体（後期成熟群）は 12 月以降に行うと考えられる (小林 未発表). 長崎県五 島の河川感潮域では 10 月から 3 月にかけて交尾が観察さ れ，1月にピークが認められている（森田 1974b）.

筆者は自然海水の流水条件下で，力二の配偶行動の水槽 観察を行い，そのプロセスを明らかにした（小林 印刷 中).モクズガニの交尾は脱皮を伴わないタイプで甲の硬 W状態で行われる，成熟脱皮は淡水域で行われ，甲の硬く なった状態で感潮域へと移動し，繁殖を行う間は脱皮を行 わない (Kobayashi \& Matsuura 1995b). また多くの海産の カニ類では, 成熟した雔の性フェロモンにより雄が誘引さ
れることが知られているが (Ryan 1966; Dunham, 1978)， モ クズガニの雄は雌の成熟程度（卵巣が発達し産卵可能かど うか）を確認できないにも関わらず交尾を挑む。しかも雄 は求愛行動や交尾前ガードにあたる行動を全く行わず，雌 をみつけると接近し捕捉して乗りかかり，そのまま交尾体 勢に入る。一方，倠の側は卵巣が成熟し産卵が可能な状態 でないと交尾ができず，卵巣が未熟な場合は交尾体丞に 入ってもその直後に体を摇さぶり雄を拒絶し，排除する. カ二類では雙の交尾期間が脱皮間期の一時期に限られる場 合, 生殖孔の脱石灰化による軟化により閉鎖が解かれ，交 尾可能となることが知られている（村井 1987; 福井 1991）. モクズガニの雌の生殖孔は可動性の蓋も無く外見からは識 別できないが, 同様の変化が雔の生殖孔に生じて産卵面前 にのみ交尾が可能になると考えられる．雄は雌に拒絶され るとすぐに雌から離れ，交尾を諦める．成熟と降河の節で 述べたように，モクズガニの倠は卵巣の発達程度に関係な く川を降るため, 繁殖期のはじめには感潮域に卵巣の未熟 な雌も多数分布している。？その結果雄は未熟な㫿にも交尾 を挑み，拒絶されることも多いと考えられる．海域では雄 は雌に比べ，岩の間隙などに媱れるよりも徘徊する傾向が 強いのも (Kobayashi \& Matsuura 1994a), 徘䧃し探索する ことで交尾可能な相手に遭遇する確率を高めていると考え られる。このように，モクズガニは倠がフェロモンにより 自分の生殖腺の発達程度を雄に知らせる様子もなく, 雄も 求愛行動も行わず相手の状態に関係なく交尾をしかけるな ど, 配偶行動に関しては雙雄間のコミュニケーションが発 達して掞らず, フェロモンによる誘引が行われるワタリガ 二科やクモガニ科, Waving などの求愛行動が見られるスナ ガニ科など，これまでに報告されている他のカニに比べて も原始的であるといえる（朝倉 1990; 福井 1991; 小林 印 刷中).

交尾は雄が㸈に向き合い乗りかかる体勢で行われるが, 交尾が成立すると雌雄とも動きが止まる．この時間は水温 が低いほど長くなり，13 分から43 分まで幅がある (Kobayashi \& Matsuura 1994b). 交尾を終えると雄は倠の背 甲に覆い被さる形で交尾後ガードに入る，ガード行動を続 ける時間に関しては筆者は定量的デー夕はとっていないも のの，夕方に雄がガードを始めて翌日の朝にはガードが解 け雌が抱卵していたのを観察した。まただードが解けずに 1 日以上続く場合は, 産卵のないまま倠が死亡するまで ガードが続けられた. 従って, 産卵行動がガードの解除に 関連していると思われる，さらに，雄よりも倠の体サイズ が大きい場合, 倠が交尾後ガードを拒絶して雄から逃げ出 す行動が観察された．なお，倠は交尾に際して卵巣が成熟 し交尾可能な場合, 寄ってくる雄をすべて受け入れ，相手 を選択して拒絶することはない，また続けて他の雄と交尾 することもできる。しかし交尾をせずそのままにしておく と倠は未受精卵を産み，やがて流失させてしまう。そのた め倠のガード拒絶行動は，卵が無䭾になるのを避けるため 
雄の精子を取りあえず受け入れたのちに，さらに他の雄と 逪遇する機会も作ることで，得られる精子の質および量を 向上させることにつながると考えられる．モクズガ二は感 潮域に降ったあと海域へ分散し，低密度下で繁殖を行う場 合もあるため，このような行動は雌の繁殖成功度を高める のに役立つと考えられる (小林 印刷中).

基本的にモクズガニの繁殖システムは乱婚型であると思 われる.モクズガニはスナガニ類にみられるような特定の 巣を持ち定住する習性はなく，慗殖に際しても配偶相手と の関係は交尾から産卵までの短い期間に限られると考えら れる. 倠は 1 回の交尾で 3 回の受精卵の産卵が可能であ ク，抱卵中には雄を拒絶する. しかし 2 回目と 3 回目の産 卵直前には他の雄の交尾を受け入れることができ，異なる 雄の精子で受精する可能性もある (小林 印刷中)。それ に対し雄は 1 回の交尾のあと翌日には交尾可能になってお り，新たな雌に交尾を挑む行動が観察される．雄は必ずし も交尾を受け入れる配偶者に道遇できるとは限らないが, 筆者は飼育環境下で最高 5 個体の雌と交尾し受精卵を産ま せることができた雄を確認している(小林 未発表).

\section{5. 崔の産毁と还発生}

モクズガニの兆は交尾の直後に産卵し, 腹肢に卵を付着 させて睬化まで抱き続ける。産卵後倠の卵巣は再び卵黄の 蓄積が進み, 多くの場合卵が餒化する頃には次の産卵が可 能な状態に発達している．産卵は 3 回可能と思われるが, 回数を経るに従い雌が疲弊するとともに産卵数は隇少する 傾向があり，雌のサイズに関わらず外見から産卵回数が推 定できる. 1 回目の産卵では腹部は前方に湾曲し，あふれ るように卵が露出しているが，2 回目になると腹部が少し 膨らみ隙間から少し卵がはみ出している程度, 3 回目は完 全に腹部が折り畺まれた状態で卵は外部からは確認できな い状態になる (Kobayashi \& Matsuura 1995b). 雌の産卵数 は甲幅の增大に応じ増加する傾向があり, 甲幅 $40 \sim 75 \mathrm{~mm}$ の範囲で 1 回目の卵数は 10 万 60 万, 2 回目は 8 万から 30 万, 3 回目は 2 万から 8 万程度である. しかし, 必ずし もすべての雌が 3 回の産卵を終えることができるわけでも なく，抱卵したままの死体も多数観察されている（小林 準備中).

卵の発生期間は水温に応じて著しく变動し，水温が $10{ }^{\circ} \mathrm{C}$ 前後に下がる冬季には, 発生に 3 ケ月近くを要する. また水温が $25^{\circ} \mathrm{C}$ 以上になる 6 月中旬や 9 月始めでは， 2 週 間程度で孵化が見られる（Kobayashi \& Matsuura 1995a）。 そのため, 福岡では早期に成熟していた少数の個体は 9 月 から 12 月にかけて 3 回産卵し，12 月頃に成熟が完了する 多数個体は 12 月から 6 月の間に 3 回の産卵を行うと推定 される (Kobayashi \& Matsuura 1995b).

\section{6. 莱窊後の死亡}

海域に分布する親ガニのほとんどは，繁殖を行う間は脱
皮成長せず，繁殖を終えると死亡すると推定される (Kobayashi \& Matsuura 1995b)。繁殖期の終わり頃には弱り きって脚が多数欠損し，鉗脚上の毛が秃げた個体も多数探 集される (Kobayashi \& Matsuura 1997)。 モクズガニの死体 は, 繁殖期を通じ河川感潮域から海岸域にかけて多数目繋 され，一部は海岸に打ち上げられる。.また，海域で採集し たカ二を飼育しても，繁殖期の終わりにはすべて死亡する. 全体的に死亡時期は雄の方が早い傾向がある（Kobayashi \& Matsuura 1995b)。なお河川の淡水域では倠雄とも，降河が 終了した冬から翌年の夏の成熟脱皮で新しい成体が出現す るまでの時期は，小型個体や未成体のみで占められるため, 成体はほとんどすべてが川を降り，以後戻らないと考えら れる(小林・松浦 1991)。つまり，モクズガ二は河川の淡 水域で成熟脱皮により成体となり, 川を降り感潮域へ達す ると，1 繁殖期（倠では最高 3 回抱卵する間）を過ごすだ けで脱皮成長せず死亡する，感潮域に降ったあとの各個体 の生存期間は，長いもので $5 \sim 6$ ヶ月である.

このように成熟脱皮がそのまま最終脱皮となる点は，他 の多くのカ二類が成熟脱皮後も成体のまま成長を続ける （倉田 1960）のとは大きく異なっている. なお力二類で成 熟脱皮が最終脱皮に相当する例は，ズワイガニChionoecetes opilio（O. Fabricius）などクモガニ類で知られている. しかしズワイガニ類で成熟脱皮後に脱皮成長しないのは䊒 のみで（吉田 1951; Diesel 1988; 風呂田 1988), モクズガ二 の場合とは異なっている，おそらく，モクズガニの死には 通し回遊という生態も影響しているのであろう。河川の淡 水域から塩分溚度をはじめとして環境の大きく異なる海域 へと降り繁殖を行うため, 生理的機能も大きく切り替わる とともに強い繁殖コストが加わり，海域で繁殖活動を続け るうちに淡水域で蓄えたエネルギーを消耗して死亡すると 考えられる，ちなみに，雌の成体を淡水で飼育すると 1 年 以上生存し，脱皮成長するものも観察された（小林 未発 表)。このように最高 3 回の産卵も可能な 1 繁殖期で寿命 が終わるという点は，強い慗殖コストにより 1 回の産卵で 死亡する例や，長い寿命の間に多回産卵を行うという例と も異なり, 重要な特性と言える.

また繁殖に参加したのち成長せず死亡することから，倠 雄とも 1 回の繁殖期の繁殖成功度がそのまま生涯繁殖成功 度を表しており，個体群内では各個体の生涯繁殖成功度に 大きな变異性が存在すると推察される．体サイズと繁殖成 功度の間に正の相関がある例はよく知られているが, モク ズガニでも体サイズと繁殖成功度との相関が考えられる。 雌では産卵数は体サイズとの間に正の相関が認められ，小 型個体と大型個体の間には数倍（1 回目の産卵で甲幅 $40 \mathrm{~mm}$ 台の 10 数万と $70 \mathrm{~mm}$ 台の 50 60 万）の開きがある (小林 準備中)。雄では大型個体ほど鉗脚は大型化し (Kobayashi \& Matsuura 1993), 交尾後ガード行動の成功率 も高いと考えられ，自分の精子で授精できる確率も高いと 考えられる。な扮他の多くのカ二類は小型の成体も脱皮成 
長を続けて大型化するため, 生涯を通じてみると小さいサ イズで繁殖に参加した個体もやがては大型化して繁殖成功 度を高め, 最初の繁殖成功度の低さを補うことができると 考えられる。それに対しモクズガニは，淡水域で成熟サイ ズが決まると将来の繁殖成功度もほぼ決まってしまう。 小 型個体は低い繁殖成功度しか得られず成長して高めること もできないまま死亡するが，大型個体は繁殖参加時に高い 繁殖成功度を得る能力を備えている。もっとも, 䧳は受け 入れ可能な状態にあれば雄のサイズに関係無く交尾を受け 入れるため, 低密度条件下では小型雄も移動性を増して配 偶者を探索し，交尾頻度を増やすことで，体サイズ差によ る不利をある程度補うことも可能と考えられる。一方，雌 の場合は体サイズにより産卵数が決まってしまい変更でき ないため, 小型個体は不利な状況を変えることはできない. 繁殖参加個体が小型個体では雄に性比が偏り，大型個体で は䧳に性比が偏っているのも，このような性により異なる 繁殖成功度の偏りで説明できるかもしれない.

このような繁殖成功度の変異性がみられる背景を生活史 全体で考えると, 淡水域で成熟するまでの成長にサイズに 応じたエネルギーと時間が必要だとすれば，繁殖参加前の 死亡率などのコストがかかることで, 体サイズの異なる個 体の適応度の間にある程度の釣り合いがとれている(つま り大型成熟個体ほど繁殖成功度は高いものの繁殖参加前の
コストは高いというトレードオフが成り立つ) 可能性も考 えられる。しかし成長に要する時間や捕食圧の強さなど不 明の点も多く，繁殖参加前のコストの差が小さい場合も考 えられるので，検証が必要である。

\section{7. メガロパの着底と稚ガニの遡上}

感潮域で稃化したゾエア幼生は, 塩分濃度が低いと生存 率も低い（石田 1976）ため, 河川流入域から海域へと流 され, 浮遊生活を送りながら海域を分散すると考えられる。 脱皮を繰り返し 5 齢までゾエアで過ごした後は, 遊泳能力 が発達したメガロパとなり, 淡水適応力も高くなる。メガ ロパは河川感潮域の上部に着底し, そこでカニへと変態す る.この水域は大潮の満潮時に塩水くさびが到達する上限 にあたり，他にゴカイ Neanthes japonica（Izuka）やケフサ イソガニ Hemigrapsus penicillatus (de Haan) など汽水性種 も分布するが，潮の引いた時は流水の塩分濃度はほとんど $0 \%$ あ゙あ.メガロパは甲幅 $1.8 \mathrm{~mm}$ 程度，1 齢稚ガニの甲 幅は $2.0 \mathrm{~mm}$ 程度であり，着底域にしばらく留まり脱皮成 長して甲幅が 5 $6 \mathrm{~mm}$ になると（最小遡上サイズ $3.5 \mathrm{~mm}$ ), ほとんどの個体は淡水域へと遡上を開始する。淡水域へ達 したのちも，遡上しながら成長を続ける（Kobayashi 1998）. なおメガロパの着底から稚ガニの遡上までの過程には, 季節性が認められ, 福岡県では大きく2つの着底群が認め
Early-reproducing group

(Small in number)
Aug. Sep. Oct. Nov., Dec., Jan., Feb. Mar. Apr., May, Jun., Jul.

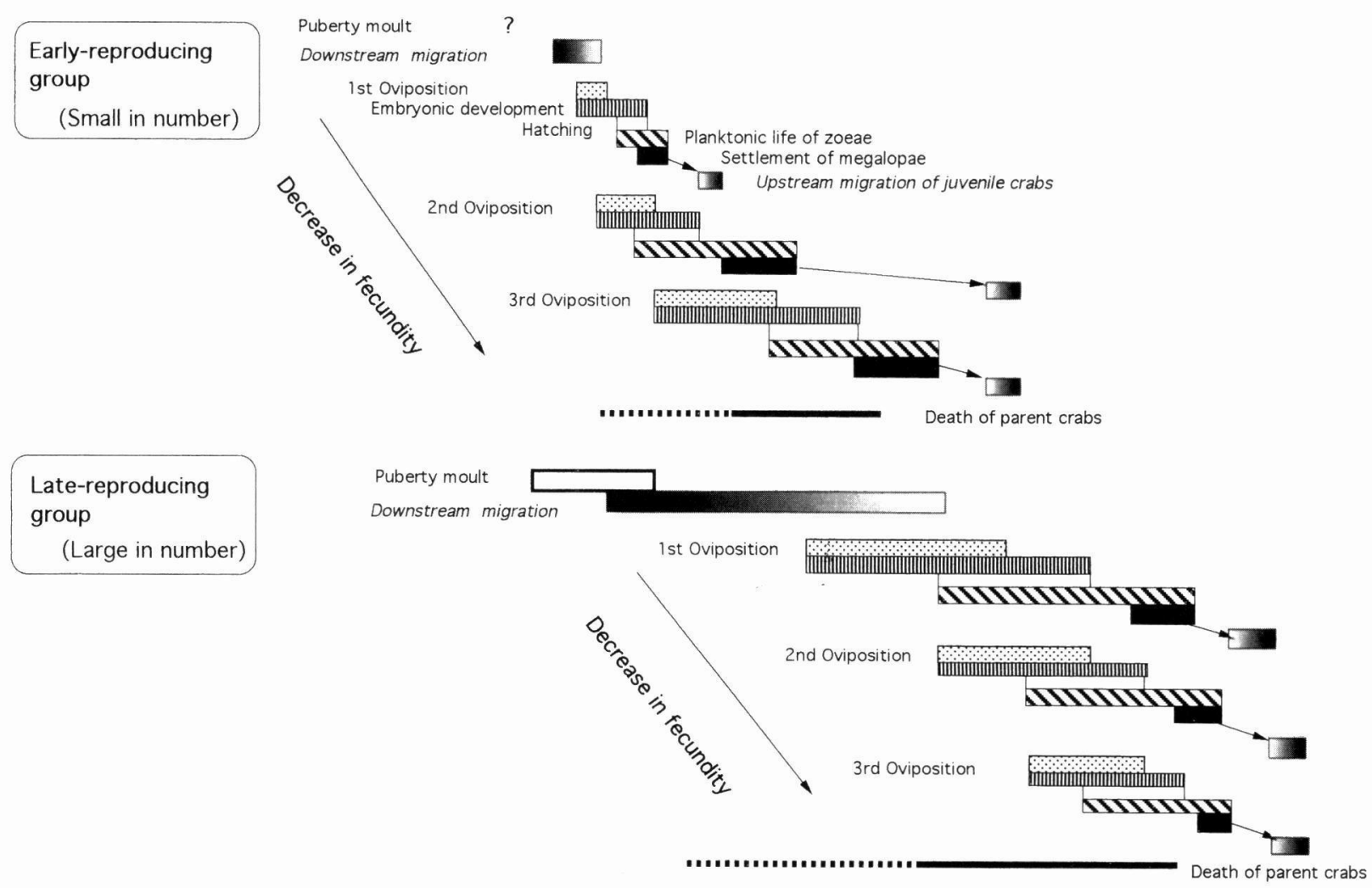

Fig. 3. Timetable of the reproductive process of Eriocheir japonica estimated from data collected in Fukuoka Prefecture. 
られる．まず，秋～冬（9月下旬から 2 月上旬）にかけて 着底するグループがあり，変態後冬までにごく一部が淡水 域へ遡上するが，ほとんどの個体は冬の間ほとんど成長も せず感潮域に留まる，3月上旬から 4 月にかけて水温が上 昇すると淡水域への遡上が行われ，成長もみられるように なり 6 月頃には甲幅 $1 \mathrm{~cm}$ 程度に達する (前期着底群). 次 に，初夏（5月下旬から 6 月中旬）に着底するグループが ある。この時期は水温も高いため成長も速く，6月中旬か ら8月上旬にかけて淡水域への遡上が行われ 9 月頃には甲 幅 $1 \mathrm{~cm}$ 程度に達している（後期着底群）（Kobayashi 1998).

さらに稚ガニの新规加入の季節性と，親ガニの産卵・睬 化時期とのつながりも推定できる（Fig. 3)。前期着底群 は，9月上旬までに成熟し川を降る早期成熟群に属する少 数の親ガニに由来している。これらの親ガニが産卵を行う のは 9 月上旬から 12 月上旬にかけてが中心であり，その 間に 3 回の産卵が行われ，後になるほど水温が低下するた め抱卵期間が長くなる傾向がある．躬化がみられるのは9 月下旬から 1 月上旬にかけてであり,ゾエア幼生が浮遊生 活を過ごす期間は 2 週間から 2 ケ程度であると推定でき る. 後期着底群は, 9 月下旬から 2 月頃にかけて川を降る 後期成熟群に属する多数の親ガニに由来している。これら の親ガニが産卵を行うのは 12 月中旬から 5 月にかけてで あり，この間に 3 回の産卵が行われ，後になるほど水温が 上昇するため抱卵期間が短縮する傾向がある。睬化はおも に2月から 6 月の間にみられ，低水温下で発生する場合 3 ケ月程度, 暖かくなって轭化する場合は 2 週間程度の浮 遊生活を過ごしたのちに着底すると推定できる（Kobayashi 1998).

\section{2. 応用的問題}

\section{1. モクズガニの寨殖戦略}

モクズガニは河川を通して海域から淡水域へと遡上し， 生活域を広げるように適応進化してきた種ということがで きる.そのため，これまで本種は進化を考える上で淡水域 への適応の面が重視され, 海域から淡水域へと分布域を広 げる途中段階にある種とみなされることが多かったようで ある(たとえば三宅 1970). しかしこのカ二の繁殖生態を 明らかにしていく上で，河川を通じて淡水域へ生息域を広 げる点だけではなく, 海域での繁殖活動を利用して分布域 を広げている点も無視できないことが明らかになってきた。

一般に淡水域は栄養がそしく変動の激しい不安定な環境 であるため, 淡水性の動物は淡水生活への適応が進むとと もに，栄養を卵内に大量に眝えた大型の卵を少数産み，幼 生の発生期間を短縮する傾向が強くなる，たとえばこのよ うな傾向は淡水性のエビ類でよく知られており（諸喜田 1979), 特にテナガエビ Macrobrachium nipponense (de Haan）では同種内に陸封化個体群と両側回遊個体群の両者
を持ち, 顕著な繁殖戦略の分化傾向が認められている (Mashiko 1990; 益子 1992). カ二類でも同梯で, 陸封化し た種群であるサワガ二類は直達発生であり, 少数の大型卵 (卵径 2 3 mm) の中で幼生期を終えた稚ガニが粰化してく る.またイワガニ科においてもジャマイカの固有種で陸封 化した 3 種 (Sesarma windsor Turkay and Diesel, S. jarvisi Rathbun, Metapaulias depressus Rathbun) は大型卵（卵径は $1 \mathrm{~mm}$ 以上) で幼生期がゾエア 2 期とメガロパ 1 期のみで あることが知られている (Anger 1995)。

モクズガニでは, 卵数に関しては甲幅 - 抱卵数の関係を アロメトリー式で回㷌させると他の海産イワガニ類（イソ ガニ Hemigrapsus sanguineus (de Haan) ・ヒライソガニ Gaetis depressus (de Haan)・ケフサイソガニ $H$. penicillatus (de Haan) 他) の延長線上にある（Fukui 1988; 小林 準備 中)。卵サイズは発眼直後の卵で 320 410 $\mu \mathrm{m}$ であり (Kobayashi \& Matsuura 1995a)，カ二類全体では大きいとは いえない (Fukui 1988; Kurata \& Matsuda 1980)。 また 5 期 のゾエアと 1 期のメガロバを過ごすため, 幼生としての発 生期間も短いとは言えない。このように，モクズガニには 淡水適応を示す大卵少産化, 幼生期間の短縮化の傾向は認 められず，他の海産種と同様な小卵多産型であるというこ とができる、つまり, 淡水へと適応する途中段階にあると いう説は繁殖形質の点からは当てはまらない。

一方繁殖のため淡水域から降ってきたカ二は，河口域か ら周辺海域へと広く移動分散するようである．筆者はモク ズガニを産する河川の河口から数 $\mathrm{km}$ 離れた海岸域でも繁 殖活動を行う個体を多数採集しており，沿岸域を放浪する カ二も目撃している (Kobayashi \& Matsuura 1994a, 1995b). 河口域では, 抱畉雌は潮汐に同調させて幼生を孵出させ, 幼生の海域への分散に役だっているようである（Yamasaki et al. 1995). 幼生も発生の初期では塩分濃度が高いほど生 存率が高まる傾向があり（石田 1976; 岡本・鈴木 1992）, 汽水域に留まる可能性は低いと考えられる。 また浮遊生活 を送る期間は水温の変動によって大きく変動し, 高水温期 は 2 週間程度でメガロパとなり着底するが, 低水温期には 2〜3 月月はかかる (小林未発表)。特に雌の産卵と抱卵の 節で述べたように，後期成熟群の 1 回目の産卵に由来する 幼生は, 親ガニの数も産卵数も多いため, 個体数が多い. これらの幼生は低水温期に発生期がさしかかるため浮遊生 活期間も長くなり，その分散の効果も大きいと予想できる. 一般に海産底生動物の中には，浮遊生活期間が数ヶ月以上 にも及ぶ長期浮遊型の種もいるが, 本種のような2 3 の場合でも浮遊期間は長い方であり（Thorson 1961）, 近接 する河川間の移動には十分役立つと考えられる．実際には 幼生が分散する程度は潮流により決まる部分が大きいと考 えられるが, モクズガニの分布する河川も内湾域に注ぐも のばかりではなく外海に面している場合も多いので, 幼生 が流れに乗り海域を移動分散している可能性は高い.

モクズガニがこのような繁殖様式を備えていることは， 
海域を通じ近接する河川どうしで遺伝子の交流があること を示している.さらに, 複数の近接する河川どうしのつな がりができることで広範囲にわたり遺伝子が共有される可 能性もある. Gao \& Watanabe（1998）は北海道から沖縄ま での 22 地域から得られたモクズガ二を用いて䤃素多型を 調べ，9つの遺伝子座で認められた変異をもとに遺伝的類 粶関係を明らかにした，多型遗伝子座率と平均へテロ接合 率は 0.0149 と 0.020 , 地域個体群間の Nei の遺伝的距離 （Nei 1972）は平均 0.0004 であり（同属種チュウゴクモク ズガニE. sinensis H. Milne-Edwards との間の 1/140), 日本 国内では地域的な種分化が生じるほどの大きな遺伝的差が 無いことが示されている，なお，同じ淡水産のカニでもモ クズガニと陸封種のサワガニ Geothelphusa dehaani（White） では対照的で，サワガニでは幼生期を欠き地域個体群どう しの交流も乏しいため，遺伝子集団に偏りが生じ，地域 個体群間の色彩変異の偏りが著しい（鈴木・津田 1991; Aotsuka et al. 1995). 5つの遺伝子座を調べることで得ら れた, 神奈川県から東京都にかけての地域個体群間の $\mathrm{Nei}$ の遣伝的距離は，同じ体色型どうしでも平均值は 0.028 か ら 0.153 であり, 全体では 0.517 という大きな値を示して いる (Aotsuka et al. 1995).

またモクズガニは河川の流程に沿って下流域から上流域 まで広く分布する傾向があり，長野県の諏訪湖や千曲川な ど標高の高い地域や，琵琶湖など，堰やダムが障害となる 可能性のある場所でも捕獲された記録があり（小林ら 1997），河川に生息する動物の中でモクズガ二ほど分布域 の広い種はまれである（Kobayashi 1998）。モクズガニは淡 水域においては砂，泥，岩，コンクリートなどいずれの底 質にも生息でき，清洌な溪流域からミズワタが生え硫化水 素が泥に溜まった富栄養な水域まで，流れさえあれば幅広 い水質域で生息している。このように環境適応力が高い上 に，垂直な壁もよじ登り，陸上も移動できるなど移動能力 も発達している。 また陸上由来のものも含め堆積物や腐 植・腐肉をおもに食べる大型底棲動物であるため，食性の 面からも競合者は少ない (小林 1999). 現在, 多くの淡水 魚が絶滅危険性のある種としてリストアップされているが, いずれも生息域・繁殖域の選択性が強く，移動能力が小さ いことで分布域が限られ，小産型で再生産効率の悪いもの が多い. 淡水域の限られた環境へ適応したことが，かえっ て閉鎖的水域で進む環境破壊による影響を強く受け，個体 数隇少を招いているのである（森 1998）。そのような種と 比較すると，モクズガニの個体群が生残する能力は明らか に高いといえよう。つまり，モクズガニは比較的安定した 環境であり開放的でもある感潮域で繁殖を行い，さらに海 域を分散することで他の河川に分布する個体群へ新規加入 個体が補給され，淡水域での生息環境に対する選好性もそ れほど強くなく，広い分布域が維持されている．そのため, 河川の淡水域で污染や乱獾などにより一時的に急激な個体 数の隇少にみまわれても，環境を整えれば隣接した他水域
からの新規加入が期待でき，時間の経過とともに個体群の 回復する見込みは大いに考えられる（小林 1999）.

\section{2. モクズガニの漁獲と保讙索業}

以上述べてきたように，本来モクズガニは幅広い環境特 性に耐性のある種であると考えられるが，現状では強い漁 獲圧による個体数減少が心配されている。このカ二は日本 の大抵の河川に分布していると考えられ，また多くの河川 で漁獲対象種とされている（小林ら 1997）。一部の農村地 域では郷土料理として漁獲され，自家消費される習慣も昔 からあるようである. カ二かごは釣り具屋で安く大量に売 られており，漁業権の設定されくない河川では，川を降る 時期になると多数のカ二かごやうけが仕掛けられ繁殖に参 加する前のカ二が捕獾されている．とりわけ降河時期の終 わり頃の雌は卵巣が発達しているため, 高值で取引きされ る傾向がある (小林ら 1997)。繁殖後の死亡の節で述べた ように，モクズガニはほとんどの個体が 1 回の繁殖期を終 えると死亡するため, 繁殖参加前の個体（特に雌）が多数 捕獲されると，個体群の再生産力を大きく低下させる。し かし, 現時点では本種の個体群動態についての明確なデー 夕は得られていない。をれは本種が回遊する習性により移 動分散が激しく，広範囲の水域に分布しており，再捕効率 も悪く，通常の個体数を推定する方法で全体を把握するこ とが困難だからである，そのため，漁獲対象である成体サ イズのカニの漁獲量の推移をもとに個体数変動を考察する 他に方法はないが, 他の漁獲種に比べて長期間にわたる統 計が残されている例は稀れであり，難しいのが現状である.

現在, 漁獲資源の保護のため, 一部の内水面漁業協同組 合ではモクズガニの漁獲に制限を設けている（1 人あたり や漁獲水域あたりでのカニかご数制限や，漁獾個体のサイ ズを大型個体に限ったり，漁獾禁止水域や禁漁期間を設け ている, 小林ら 1997).

さらに放流事業も行われている．種苗生産した稚ガニの 放流は資源保護に有効な手段として期待されている. 感潮 域で捕えた抱卵雌を海水で飼育し、ゾエア幼生を㽟化させ る. 続いて幼生をアルテミアなどを与えて育て，稚ガニに まで変態させる．やがて淡水に馿化させ，しばらく成長さ せたのち河川に放流する（石田 1976）。種苗生産した稚ガ 二を大型水槽内で飼育していると，やがて水槽内を群れて 一定方向入循環するのが観察されるようになるので，放流 する時期を決めることができる (太田川漁協 私信)。モク ズガニの種苗は飼育中の生残率も比較的高く，この方法は 福岡県豊前水産試験場で最初に考案されたあと（石田 1976）, 現在広島県, 大分県, 山口県, 新潟県などの水産 試験場, 漁業協同組合, 漁業公社などで行われ，一度に数 千から数万尾の単位での放流が行われている（小林ら 1997).

自然状態では，稚ガニは汽水域からおもに甲幅 $5 \sim 6 \mathrm{~mm}$ 以上のサイズで淡水域へ遡上し，成長を続ける（Kobayashi 
1998）。遡上時期には，群れをなして移動する稚ガニが観 察されている（野中 1994; 小林ら 1997），魚類による遡上 中のカ二への捕食圧は高いと考えられ, 実際に筑後川では 稚ガニで胃が充满したニゴイ Hemibarbus labeo barbus (Temminck et Schlegel) が観察されている（竹下・木村 1995）。放流に際しては捕食圧を低くする必要がある。 Suzuki et al.（1998）は生物相の豊富な下流域と筫困な上流 域での放流個体にかかる捕食の可能性を調べ, 生物相が豊 富であれば魚類の捕食圧も他の慨生物に分散され，カ二の 生残率も高いことを指摘している。 また, 近年の河川改修 工事により讙岸のコンクリート張りが進み，単純化された 河川環境では，生物相が筫困である上に身を隠す場所も少 なく，カ二は高い捕食圧を受けると考えられる，そのため 放流効率を高めるためには，カ二が分散できる場所が上流 部に残されている下流域で，しかも植生や転石に富み自然 度が高い場所に, 河川で多くの遡上個体が観察される初夏 （後期着底群の遡上時期）を選んで行うのが望ましいと考 えられる (Kobayashi 1998)。

その他, ある程度成長したカ二を他地域から取り寄せて 放流することも行われている（小林ら 1997）。この場合， 非漁業水域から取り寄せるものと, 大河川などの他の漁業 水域から供給されるものとがある。しかし供給源を選ぶ根 拠も明確ではなく，供給源の地域個体群に負担がかかるこ とも考えられる. また種苗生産した稚ガ二の放流に比べ规 模も小さいため, 実際にどの程度の効果が及んでいるかも 明らかではない。

放流事業に関しては，近年魚類で遺伝子レベルでの地域 個体群に及ほす影響が懸念されている（原田 1998）。他水 域から得られた放流個体は, 本来の個体群と違う遺伝子組 成を含む可能性があり, 遺伝子集団の構成を乱し, 個体群 の性質を変えることも考えられる，また継代飼育を続けて きて遺伝子組成の限られた親から得られた子を放流するこ とで, 集団の遺伝子の多㥞性を低下させる可能性もある.

しかし, モクズガ二の場合は繁殖戦略として海域を分散 する方法をとっていることもあり，各河川の個体群が海域 を通じて交流し, 個体群ごとの遗伝子の特殊化の傾向が弱 く地域問の差は小さい（Gao \& Watanabe 1998）。 またモク ズガニの継代飼育は現時点では行われていないこともあり， 放流個体の遗伝的な多様性が著しく低下寸ることはないと 考えられる，伏屋ら（1997）は，島根県で種苗放流を行っ ている河川と行っていない河川で得られたモクズガニを用 い，アイソザイム分析により比較した，10 䣼素 16 遗伝子 座の調查により得られた 6 遺伝子座の変異を比較すると, 平均へテロ接合率は 0.029 と 0.027 で差は小さく, Nei の遺 伝的距離も0.0001 というきわめて小さな值であり, 種苗放 流による遺伝的変異性隇少の傾向は認められなかった。 こ のように，モクズガニの放流については遺伝子レベルでの 問題は淡水魚ほど大きくはないと考えられる.

\section{3. 同属糧チュウゴクモクズガニの現状}

モクズガニの同属種に，チュウゴクモクズガニE. sinensis H. Milne-Edwards がある．このカニは形態的には甲の突 起の数や形状などわずかの点を除いてモクズガ二に酷似し ており，同様な降河型の通し回遊を行う習性が知られてい る (Peters \& Panning 1933). 非常に近縁なため 2 種を同種 として扱うことを提唱する研究者もいるが（Li et al. 1993）, 遺伝子レベルの調查によると近縁な異種として扱うことに 定着しそうである（高・渡遥 1998）。原産地は朝鮮半島西 岸部，黄海沿岸部から香港にかけての中国沿岸部之，黄河 や長江などそれらの地域に注ぐ河川である，幼生期はゾエ ア5 期とメガロパ 1 期であり, 最大 3 4 ヶ月の浮遊期間を 過ごし（Panning 1939），ゾエア期に海域へ分散しメガロパ 期以降に河口へ侵入し上流へ遡上することが推定されてい る(Anger 1991). 未成体は大陸の内陸部へ $1000 \mathrm{~km}$ 以上 遡上する (Clark et al. 1998). また中国や日本では上海ガニ の名称で中華料理の食材として高値（日本では kg あたり の卸值で約 1 万円）で取引きされている．中国内の漁獲量 も年々增加する傾向にあり乱獲の危険性もあるため漁獲や 輸出に制限がかけられている．中国国内での種苗生産や池 中養殖も行われており，ある程度の収益も得られている (高ら 1998).

一方，チュウゴクモクズガニは帰化生物としてヨーロッ パやアメリカ合紊国にまで分布域を広げている。ヨーロッ パでは 1910 年代にドイツで初めて確認され（Peters \& Panning 1933), 南はフランスの地中海沿岸部, チェコ, 北は フィンランドやロシア, オランダ, ベルギー，イギリスに かけて分布を広げている。近年では，一時期隇少していた 個体数が増加する傾向にあり，特にイギリスのテムズ川で は 1990 年代になってから大量に增加している (Clark et al. 1998）。アメリカ合衆国では, 1970 年代以降五大湖のエ リー湖, ルイジアナ州ミシシッピー川デルタ地帯, サンフ ランシスコ湾で確認されている．いずれの地域も従来の生 態系や漁業へ及ほ寸影響が心配されており，米国内での チュウゴクモクズガニの商業取引きが禁止されるに至って いる (Cohen \& Carlton 1997). 帰化の原因としては, 幼生 が船のバラストタンクを通じて運ばれたとする説が最も有 カであり，また商業価値が高いため，業者に持ち込まれた カニが放流されたか逃げ出したという可能性もある（Peters \& Panning 1933; Cohen \& Carlton 1997). いずれにしても, 先にモクズガニについて述べた幼生期間の長さと分散力, 着底後の高い環境適応力が，チュウゴクモクズガニにおい てあてはまり，㷌化をもたらしたことを示している。

しかし同樣な通し回遊を行うにも関わらずモクズガニの 海外への帰化は知られていない，逆に日本でのチュウゴク モクズガニの帰化も報告がない，一つの可能性としては， モクズガニは分布域の一部に朝鮮半島やロシア沿海州の日 本海沿岸域を含むものの, 分布域の大半が日本列島全域と 台湾を含む島舆部であり，チュウゴクモクズガニが分布し 
ている，干满の差が激しく流れの緩やかな大河川の流域に あるという大陸的な環境ではないという点が考えられる。 つまり,より原産地の環境に近い大陸的な環境に, チュウ ゴクモクズガニが分布を広げることができたと考えられる。

原産地の中国では資源の枯渴が心配されているにも関わ らず，㷌化した地域では漁獲されないこともあり大量増殖 が問題となっている現状は，モクズガニ類の繁殖力と人間 の及ほす個体群への影響力の関係を暗示しているといえよ j.

辞：本総説をまとめるに際しお世話になった九州大学水産 学第一講座の松山倫也博士をはじめとするスタッフの皆様, 千葉 県立中央博物館の朝倉彰博士ならびに匿名の查読者の方々にお礼 を申し上げる。

\section{引用文 献}

Anger, K. 1991. Effects of temperature and salinity on the larval development of the Chinese mitten crab Eriocheir sinensis (Decapoda: Grapsidae). Marine Ecology Progress Series, 72: 103-110.

Anger, K. 1995. The conquest of freshwater and land by marine crabs: adaptations in life-history patterns and larval bioenergetics. Journal of Experimental Marine Biology and Ecology, 193: 119-145.

Aotsuka, T., T.Suzuki, T. Moriya and A. Inaba 1995. Genetic differentiation in Japanese freshwater crab, Geothelphusa dehaani (White): Isozyme variation among natural populations in Kanagawa Prefecture and Tokyo. Zoological Science, 12: 427-434.

朝倉 彰 1990. 十朋甲殼類の交尾行動・配偶システムとその進化 一とくに交尾前ガードに関する話題を中心に一. 生物科学, 42 : 192-200.

Clark, P. F., P. S. Rainbow, R. S. Robbins, B. Smith, W. E. Yeomans, M. Thomos and G. Dobson 1998. The alien Chinese mitten crab, Eriocheir sinensis (Crustacea: Decapoda: Brachyura), in the Thames catchment. Journal of the Marine Biological Association of the United Kingdom, 78: 1215-1221.

Cohen, A. N. and J. T. Carlton 1997. Transoceanic transport mechanisms: introduction of the Chinese mitten crab, Eriocheir sinensis, to California. Pacific Science, 51: 1-11.

Diesel, R. 1988. Male-female association in the spider crab lnachus phalangium: the influence of female reproductive stage and size. Journal of Crustacean Biology, 8: 63-69.

Dunham, P. J. 1978. Sex pheromones in Crustacea. Biological Reviews, 53: 555-583.

Fukui, Y. 1988. Comparative studies on the life history of the grapsid crabs (Crustacea, Brachyura) inhabiting intertidal cobble and boulder shores. Publications of the Seto Marine Biological Laboratory, 33: 121-162.

福井康雄 1991. 力二類の配偶行動 (総説). 日本ベントス学会 誌, 40: 35-46.

風员田利夫 1988. 移入種イッカククモガニPyromaia tuberculataの 生態 (予報)。日本ベントス研究会誌, 33/34: 79-89.

伏屋玲子・高 天翔・横田賢史・岩本美央・北田修一・渡邉精一 1997. モクズガ二の種苗放流が天然集団におよはす遗伝的影響 の検証. 水産增殖, 45: 25-29.

高 天翔・渡邉精一・横田賢史 1998. チュウゴクモクズガ二の盖 殖. Cancer (日本甲殼類学会会員連絡誌)，7:21-24.

高 天翔・渡邉精一 1998. モクズガニと近縁種チュウゴクモズ ガ二の遗伝的類緣関係. 水産增殖, 46: 171-176.

Gao, T. and S. Watanabe 1998. Genetic variation among local populations of the Japanese mitten crab Eriocheir japonica De Haan. Fish- eries Science, 64: 198-205.

Goto, A. 1993. Clinal life-history variation in the river-sculpin, Cottus hangiongensis: an example of phenotypic plasticity. Japanese Journal of Ichthyology, 39: 363-370.

原田泰志 1998. 放流と遗伝的多様性. 魚から見た水懪境一復元生 態学に向けて／河川編一, 森 諴一(編)，pp. 41-47. 信山社 サイテック, 東京,

石田雅俊 1976. モクズガニの生態と增殖に関する研究. 昭和 49 年度福岡県豊前水産試験場研究業務報告, 1-40.

Kobayashi, S. 1998. Settlement and upstream migration of the Japanese mitten crab Eriocheir japonica (De Haan). Ecology and Civil Engineering, 1: 21-31.

小林 哲 1999. 通し回遊性甲殻類モクズガニの生態一回遊過程と 河川㻴境一. 生物科学, $51: 93-104$.

小林 哲印刷中. モクスガ二の配偶行動. 水生無脊椎動物学の最 近の進歩, 奥谷喬司・小黒千足·太田 秀·上島 励 (編) 東 海大学出版会, 東京.

小林 哲・松浦修平 1991. 鹿児島県神之川におけるモクズガニの 流程分布, 日本水産学会誌, 57: 1029-1034.

小林 哲・松浦修平 1992. モクズガ二雌の成長と成熟に伴う外骨 格形態の変化, 甲殼類の研究, 21: 159-168.

Kobayashi, S. and S. Matsuura 1993. Ecological studies on the Japanese mitten crab Eriocheir japonicus De Haan-III. Relative growth of the chela and soft-hair distribution on the chela. Benthos Research, 45: 1-9.

Kobayashi, S. and S. Matsuura 1994a. Occurrence pattern and behavior of Japanese mitten crab Eriocheir japonicus De Haan in the marine environment. Benthos Research, 46: 49-58.

Kobayashi, S. and S. Matsuura 1994b. Variation in the duration of copulation of the Japanese mitten crab Eriocheir japonicus De Haan. Benthos Research, 48: 29-39.

小林 哲・松浦修平 1995. モクズガ二. 日本の希少な野生水生生 物に関する基礎資料（II）。VII. 甲殼類. 日本水産資源保護協 会, 東京, pp. 649-656.

Kobayashi, S. and S. Matsuura 1995a. Egg development and variation of egg size in the Japanese mitten crab Eriocheir japonicus (De Haan) in its marine phase. Benthos Research, 48: 29-39.

Kobayashi, S. and S. Matsuura 1995b. Reproductive ecology of the Japanese mitten crab Eriocheir japonicus (De Haan) in its marine phase. Benthos Research, 49: 15-28.

Kobayashi, S. and S. Matsuura 1995c. Maturation and oviposition in the Japanese mitten crab Eriocheir japonicus (De Haan) in relation to their downstream migration. Fisheries Science, 61: 766-775.

Kobayashi, S. and S. Matsuura 1995d. Population structure of the Japanese mitten crab Eriocheir japonicus (De Haan)-clinal variations in size of maturity. Crustacean Research, 24: 128-136.

Kobayashi, S. and S. Matsuura 1997. Incidence of limb loss and bald chelipeds in the Japanese mitten crab Eriocheir japonica (De Haan) in its marine phase. Benthos Research, 52: 61-68.

小林 哲・固平真明・米司 隆・松浦修平 1997. モクズガ二Eriocheir japonica (de Haan) の生態と漁業実態に関するアンケー 卜調查. 九州大学農学部学芸雑誌, 52: 89-104.

倉田 博 1960 . 甲款類の脱皮時における長さの増大について. 北 海道区水産研究所研究報告, 22: 1-48.

Kurata, H. and T. Matsuda 1980. Larval stages of a parthenopid crab, Parthenope validus, reared in the laboratory and variation of egg size among crabs. Bulletin of the Nansei Regional Fisheries Research Laboratory, 12: 31-42.

Li, G., Q. Shen and Z. Xu 1993. Morphometric and biochemical genetic variation of the mitten crab, Eriocheir, in southern China. Aquaculture, 111:103-115.

Mashiko, K. 1990. Diversified egg and clutch sizes among local populations of the fresh-water prawn Macrobrachium nipponense (de Haan). Journal of Crustacean Biology, 10: 306-314. 
益子計夫 1992. テナガエビの大卵少産・小卵多産. 生物の科学 遗伝 別冊 4 号, pp. 7-16.

McDowall, R. M. 1992. Diadromy: origins and definitions of terminology. Copeia, 1992: 248-251.

三宅貞祥 1970. 甲款類. 馬渡静夫 (編), 現代生物学大系- 無脊 椎動物 A. 中山書店, 東京, pp. 256-296.

森 誠一 (編) 1998. 魚から見た水環境一復元生態学に向けて／ 河川編一，信山社サイテック，東京，243 pp.

森田豊彦 1974a. モクズガニ Eriocheir japonica De Haan の発生学 的考察. 動物学雑誌, 83:24-81.

森田豊彦 1974b. モクズガニ Eriocheir japonica De Haanの交尾習 性について. 甲殼類の研究, 6:31-47.

村井 実 1987. カ二類の交尾と雃による精子保存. 海洋科学, 19: 118-122.

Myers, G. 1949. Usage of anadromous, catadromous and allied terms for migratory fishes. Copeia, 1949: 89-97.

Nei, M. 1972. Genetic distance between populations. American Naturalist, 106: 283-292.

野中繁孝 1994. 魚道とその効果. 水辺ビオトープーその基礎と事 例一. 自然環境復元研究会 (編)，信山社サイテック，東京。 pp. 126-142.

岡本一利・鈴木三夫 1992. モクズガニの幼生と稚ガニの生残, 成 長に及ほす水温, 塩分浱度の影䍌. 静岡県水産試験場研究報 告, 27:21-32.

Panning, A. 1939. The Chinese mitten crab. Report of the Board of Regents of the Smithsonian Institution (Washington), 3508: 361-375.

Peters, N. and A. Panning, 1933. Die chinesische Wollhandkrabbe (Eri- ocheir sinensis H. Milne Edwards) in Deutscheland. Zoologischer Anzeiger (Suppliment), 104: 1-180.

Ryan, E. P. 1966. Pheromone: evidence in a decapod crustacean. Science, 151: 340-341.

酒井 恒 1976. モクズガ二, 日本産蟹類. 講談社, 東京, pp.401-403.

鈴木廣志・津田英治 1991，鹿児島県におけるサワガニの体色変異 とその分布，日本ベントス学会誌，41: 37-46.

Suzuki, T., T. Hamano, A. Araki, K.-I. Hayashi, H. Fujimura and Y. Fujita 1998. Predation by fishes on released seedlings of the Japanese mitten crab Eriocheir japonica. Crustacean Research, 27: 1-8.

諸喜田茂充 1979. 琉球列島の陸水エビ類の分布と種分化について -II. 琉球大学理学部紀要, 28: 193-278.

竹下直彦・木村清朗 1995. 筑後川におけるニゴイの食性日本水産 学会誌, 61: 860-867.

Thorson, G. 1961. Length of pelagic larval life in marine bottom invertebrates as related to larval transport by ocean currents. In, Oceanography, Sears, M. (ed.), American Association of Advancement of Science, Washington, D.C., pp. 455-474.

塚本勝巳 1994. 通し回遊魚の起源と回遊メカニズム．川と海を回 遊する淡水魚一生活史と進化一. 後藤 晃・塚本勝巳 - 前川光 司 (編), 東海大学出版会, 東京, pp. 2-17.

Yamasaki, S., Sakamoto, H. and H. Hirata 1995. Influences of salinity on hatching and zoeal growth of a catadromous crab, Eriocheir japonicus. Suisanzoshoku, 43: 423-428.

吉田 裕 1951. 有用カ二類の雄に見られる大きさの相違と其の 原因について．日本水産学会誌，16: 90-92. 